\title{
VÝZNAMNÝ PROBLÉM VO SVETE - CHUDOBA
}

\author{
Ján Veselovský, Martin Peihoffner
}

\begin{abstract}
Poverty is these days quite common; however, just a few people can imagine it in all of its dimensions. Poverty does not mean only the absence of financial resources. It represents significantly more problems. Every region of the world characterizes other deprivation form of the poverty. Usually, it is not a problem of individuals but of the entire population, resulting in lack of food, water or housing. The aim of the paper is to describe the main causes of poverty in individual regions of the world and to analyze selected indicators of poverty.
\end{abstract}

Keywords: poverty, poverty indicators, causes of poverty, world Úvod

Vo svete sa stretávame $\mathrm{s}$ pojmom chudoba $\mathrm{v}$ súčasnosti celkom bežne. Avšak len málo l'udí si dokáže tento pojem predstavit' v jeho všetkých dimenziách. Chudoba nepredstavuje len absenciu finančných prostriedkov. V tomto slove sa skrýva podstatne viac problémov, ako len tých, ktoré sú spojené s peniazmi. Chudoba predstavuje v jednotlivých regiónoch sveta inú formu deprivácie. Často nejde len o problém jednotlivca, ale celej populácie, ktorá nemá dostatok potravy, vody či strechu nad hlavou.

Práve tomuto problému sa budeme venovat' aj v predkladanom príspevku, kde popisujeme hlavné príčiny chudoby $\mathrm{v}$ jednotlivých regiónoch sveta a analyzujeme vybrané indikátory chudoby.

\section{Teoreticko-metodické východiská}

Problém chudoby má viacero rozmerov a jeho priestorové rozmiestnenie je zložité. Identifikácia priestorového vymedzenia aspektov chudoby má vo svete mnoho úskalí hlavne kvôli nedostatku teoreticko-metodologických východísk. Teritoriálne vymedzit' chudobu je z mnohých hl'adísk náročné. Podl'a toho, ako definujeme chudobu, aký koncept si zvolíme a aké indikátory budú predmetom sledovania, bude vyzerat' aj priestorové rozloženie chudoby.

V minulosti sa všeobecne hovorilo, že najväčší vplyv na chudobu vo svete má ekonomický rast danej krajiny. Existuje však vel'ké množstvo situácií, ktoré sa priamo podiel'ajú na vzniku tohto nežiaduceho sociálneho javu vo svete. V literatúre sa stretávame s vel'kým množstvom názorov, $\mathrm{v}$ rámci ktorých sa každý autor stavia $\mathrm{k}$ príčinám chudoby trochu iným spôsobom. 
Ked'že chudoba je problémom všetkých krajín a spoločností, je predmetom vedeckého výskumu už takmer dve storočia. Zvládnut' chudobu a eliminovat' všetky jej riziká si vyžaduje okrem pragmatických opatrení aj exaktný výskum, ktorý by pomohol k jej predvídaniu a systematickému riešeniu (Alcock, 1993).

Podl'a Michálka (2000) chudoba nie je len existenčným stavom, ale aj politickým a praktickým konceptom, ktorý popisuje určitý stav chudoby, indikuje určitú predstavu o jej príčinách a dôsledkoch, o jej obsahu, o sociálnom statuse chudobných a ich prestíži a pod. Čo sa týka teritoriálnych aspektov, vystupuje diferenciácia medzi rurálnou a urbánnou chudobou. Kým vo väčšine krajín sveta viac prevažovala rurálna chudoba, ktorá mala za následok výrazný migračný pohyb, v súčasnosti v niektorých krajinách (Holandsko, USA a pod.) je hlavným problémom urbánna chudoba obyvatel'stva. $\mathrm{V}$ mnohých prípadoch je táto chudoba ovel'a nebezpečnejšia (vyššia bieda, vyššia sociálna patológia a pod.).

Collier (2009) hovorí v rámci geografického vymedzenia chudoby o tzv. pasciach chudoby, ktoré bránia chudobným krajinám v ich rozvoji, pričom za rozhodujúce považuje politické príčiny. Konkrétne uvádza pascu konfliktov, ale aj pascu v oblasti prírodných zdrojov, pascu, ktorej čelia krajiny bez prístupu k moru a so zlými susedmi a pascu zlej vlády v malej krajine, čo je evidentné najmä v tzv. zlyhávajúcich štátoch. Bariéry rozvoja sú spravidla vzájomne prepojené, čo ich pôsobenie ešte znásobuje.

Gregory et al. (2011) tvrdí, že chudobu nie je možné l'ahko definovat'. O chudobe hovorí, ako o stave, kedy osoba nemôže uspokojit' svoje základné l'udské potreby. Problematikou l'udských potrieb sa zaoberal americký psychológ Abraham W. Maslov, ktorý l'udské potreby hierarchicky zoradil podl'a nutnosti ich uspokojenia. L'udské potreby rozdelil na potreby vyššieho a nižšieho rádu - za základné l'udské potreby teda možno označit' potreby nižšieho rádu. Pokial' tieto fyziologické potreby, potreby istoty a bezpečia nie sú zabezpečené, dochádza $\mathrm{k}$ deprivácií a následne $\mathrm{k}$ chudobe.

Príčiny rozdielneho spoločenského a hospodárskeho vývoja, ktorý následne vedie $\mathrm{k}$ vzniku chudoby vo svete možno hladat' $\mathrm{v}$ odlišných prírodných podmienkach, akými sú geografická poloha, dostupnost' prírodných zdrojov a pod. (Bolečeková, 2013).

$\mathrm{Na}$ základe rozširovania chudoby $\mathrm{v}$ určitých oblastiach, vznikajú nové geografické témy o chudobe, týkajúce sa napr. rozmiestnenia nových subkultúr chudoby a cyklov chudoby, nerovnosti a deprivácií. Všetky tieto javy a prejavy sa skúmajú najmä v kontexte s novými javmi, ako je globalizácia trhu, integrácia ekonomík, migrácia pracovných síl, presun a šírenie chudoby do susedstva, delimitácia vo vnútri mesta a pod..

Z pohl’adu medzinárodných organizácií je najdôležitejšia definícia a analýza chudoby od Svetovej banky ktorá určuje presnú hranicu použitel'nú na celom svete. Táto hranica je pre extrémnu chudobu určená finančným príjmom 1,25 \$ na deň a 2 \$ na deň pre chudobu, ktorá je taktiež vel'mi vážna. V roku 2005 žilo v 
rozvojových krajinách asi 1,4 miliardy l'udí pod hranicou extrémnej chudoby. Ludí žijúcich $\mathrm{s}$ príjmom pod 2 \$ na den̆ bolo $\mathrm{v}$ roku 2005 asi 2,6 miliardy (www.worldbank.org, 2017).

V roku 2000 bol vytvorený projekt Voices of the poor (Hlasy chudobných) pod záštitou Svetovej banky. V tomto projekte sa zúčastnilo viac než 60 tisíc l’udí trpiacich chudobou $\mathrm{z}$ celého sveta. Projekt dokázal, že pre chudobných $\mathrm{v}$ rozvojových krajinách nie je zd’aleka príjem jedinou alebo najdôležitejšou súčast'ou chudoby. $Z$ dimenzie chudoby možno považovat' zdravie, vzdelanie, prístup k službám, podvýživu, infraštruktúru, bezpečnost', nedostatok politickej a náboženskej slobody a sociálne vylúčenie (www.rozvojovka.cz, 2016).

UNDP (United Nations Development Programme) charakterizuje chudobu podobne ako Svetová banka pomocou príjmov, ale upozorňuje aj na to, že chudoba taktiež zahrňuje nedostatočný prístup ku vzdelaniu, $\mathrm{k}$ základnej zdravotnej starostlivosti, $\mathrm{k}$ pitnej vode, zlé sociálne postavenie $\mathrm{v}$ živote a nemožnost' ovplyvnit' politické dianie v krajine (www.ipc-undp.org, 2006).

OSN (Organizácia Spojených národov) definuje chudobu nasledovne: „Chudoba je odoprenie možností a príležitostí, porušovanie l'udskej dôstojnosti. To znamená neschopnost' účasti jednotlivca $\mathrm{v}$ spoločnosti, nedostatok potravy a ošatenia pre rodinu, nemožnost' navštevovat' školu či zdravotnícke zariadenie, žiadne vlastníctvo pôdy pre pestovanie potravín alebo práce, ktorá by zabezpečila príjem. $Z$ toho vyplýva neistota, bezmocnost' a vylúčenie jednotlivca, domácností či celých komunít" (Gordon, 2005).

OSN, podobne ako Svetová banka, uprednostňuje pohl'ad na chudobu z viacerých dimenzií. Obe organizácie využívajú niekol'ko indikátorov, ktoré zahrňujú väčšie množstvo aspektov (napr. Index l'udského rozvoja, Viacnásobný index chudoby a pod.).

ICESCR (International Comittee on Economic, Social and Cultural Rights) definuje chudobu ako l’udskú situáciu charakterizovanú trvalým alebo chronologickým odopieraním zdrojov, schopností, volieb, bezpečia a slobôd nutných na to, aby človek dosiahol primeranú životnú úroveň a d'alšie občianske, kultúrne, hospodárske, politické a sociálne práva.

Definícia chudoby podla Európske únie predstavuje širší koncept, ktorý vyjadruje jednak východisko chudoby a jej dôsledky. Chudoba sa vzt'ahuje k spotrebnému štandardu, dosahovaniu nízkych alebo neadekvátnych materiálnych prostriedkov. Niektoré skupiny, aj ked' nie sú chudobné, môžu byt' systematicky exkludované, napr. rasové alebo etnické menšiny, postihnutí, ženy, a pod. Zároven̆ je sociálna exklúzia vždy spojená s inklúziou; ak sú l'udia vylúčení z jednej sféry, zároveň sú začlenení do sféry inej (www.cphr.sk, 2013).

V Českej republike poukazuje na symbiotickú prepojenost' chudoby a populačného vývoja napr. Hübelová (2010). Na Slovensku sa problematike chudoby (analyzoval situáciu v deviatich okresoch východného Slovenska) venoval Michálek (2004). Falt’an a Pašiak (2004) na území Slovenska vyčlenili 
región chudoby vychádzajúci z južných okresov Nitrianskeho kraja a smerujúci na severovýchod a juhovýchod.

$\mathrm{V}$ príspevku prioritne analyzujeme jednotlivé regióny sveta prostredníctvom údajov zo Svetovej banky, ktoré môžu indikovat' chudobu vo svete. Ide o:

- hrubý priemerný príjem na osobu prevedený pomocou parity kúpnej sily na hodnotu dolára. Tento indikátor je jediné približne objektívne bežné meradlo relatívneho ekonomického bohatstva daného štátu.

- nezamestnanost' poukazuje na podiel pracovnej sily, ktorá nie je zamestnaná ale je k dispozícii pre hl'adanie zamestnania. Nezamestnanost' je sama o sebe sociálny jav, ktorý negatívne vplýva na celkovú ekonomickú situáciu daného štátu, nie len na nezamestnaného jednotlivca.

- gramotnost' populácie sa vyjadruje ako percento obyvatel'ov, ktorí môžu s porozumením, čítat' a písat' krátke a stručné vyhlásenia. Všeobecne platí, že gramotnost' taktiež zahŕňa aj počítanie, $\mathrm{v}$ tomto prípade to znamená vykonávat' jednoduché aritmetické kalkulácie. Tento ukazovatel' sa vypočíta ako podiel počtu gramotných osôb k celkovému obyvatel'stvu a vynásobením čísla 100 (\%).

- hrubá miera úmrtnosti je uvedený počet úmrtí na 1000 (\%) obyvatel'ov počas jedného roka. $\mathrm{V}$ rámci chudoby sa úmrtnost' uvádza ako faktor, ktorý reflektuje úroveň zdravotnej starostlivosti daného štátu.

- odhadovaná dížka života pri narodení udáva počet rokov, ktoré sa môže osoba dožit' za predpokladu, že sa doterajší stav mortality nezmení počas celej doby jej života.

Svetová banka k uvedeným indikátorom poskytuje údaje k roku 2015, prípadne 2014. Tiež môžeme vidiet', že k niektorým štátom dáta na webovej stránke Svetovej banky dostupné nie sú.

\section{Indikátory chudoby}

V odbornej literatúre sa môžeme stretnút' s mnohými deleniami ukazovatel'ov chudoby. Ako už bolo vy̌šsie spomínané, indikátory je možné rozdelit' napr. na monetárne a nemonetárne alebo podl'a úrovní - úroveň regiónu, úroveň spoločnost' a úroveň domácnosti a jednotlivca (Haughton, Khandker, 2009).

Medzi monetárne ukazovatele patrí prijem a spotreba. Množstvo ukazovatel'ov je založených na koncepte príjmov. Výhodou indikátorov, ktoré čerpajú z konceptu príjmov je, že meranie chudoby na ich základe dovol'uje rozlíšit' zdroje príjmov, pričom príjmy je možné l'ahšie porovnat's údajmi z iných zdrojov. Avšak je dôležité poukázat' aj na význam spotreby v rámci chudoby, nakol'ko lepšie približuje osobný životný štandard ako príjem. Príjem, ako indikátor chudoby, je len zložka súčasti ktorá umožňuje spotrebu. Výhoda príjmov je, že sa dajú rozlíšit' ich zdroje. Spotreba reflektuje reálnu životnú úroveň lepšie ako príjem, nakol'ko odráža aj to, či domácnost' má ako získat' úspory alebo sa 
dostat' na úverový trh, nie len schopnost' nadobudnút' tovary a služby (Coudouel, Hentschel, Wodon, 2002).

Prijem je výrazne priestorovo diferencovaný. To znamená, že jeho úroveň a nerovnosti sú podmienené aj geograficky. Výrazné geografické rozdiely spôsobené príjmom a $\mathrm{s}$ tým súvisiaca hustota populácie $\mathrm{s}$ nízkym príjmom $\mathrm{v}$ určitých regiónoch má za následok prehlbovanie chudoby týchto regiónov a ekonomické problémy ich obyvatel'stva (Michálek, 2007).

S chudobou taktiež súvisí aj zdravie človeka. Chudobní l’udia si nemôžu dovolit' dostatočnú zdravotnú starostlivost'. Preto d'alší indikátor chudoby je zdravotný stav. $\mathrm{V}$ odbornej literatúre sa stretávame $\mathrm{v}$ rámci zdravotného stavu $\mathrm{s}$ indikátormi, akými sú váha, výška alebo zdravotné ochorenia, ktoré sú ovplyvňované chudobou - ako napr. AIDS, malária či ebola. Svetová banka sem zarad'uje aj odhadovanú priemernú dížku života osoby v danom štáte, pokial' sa v ňom nezmení situácia. V prípade absencie týchto dát sú využívané údaje ako napr. počet návštev u lekára, prístup $\mathrm{k}$ zdravotnej pomoci alebo počet očkovaných jedincov. Svetová banka $\mathrm{v}$ rámci indikátorov zdravotného stavu populácie poskytuje najviac údajov o úmrtiach na 1000 obyvatel'ov (Coudouel, Hentschel, Wodon, 2002).

Konkrétnym indikátorom zdravia vo svete sú tropické choroby. V chudobných regiónoch sa často stretávame s ochorením, ako je napr. malária. $95 \%$ prípadov sa vyskytuje v subsaharskej Afrike. Práve vyššie spomínaný prístup k zdravotnej pomoci je pri tomto ochorení kl'účový, nakol'ko neimúnna osoba bez liečby umiera do dvoch týždňov (Benca, 2012).

Chudoba má vplyv aj na vzdelanie spoločnosti. Najčastejšie používaným indikátorom vzdelania $\mathrm{v}$ rámci sledovania chudoby je úroveň gramotnosti. Určitá úroveň negramotnosti sa považuje za hranicu chudoby. Prieskumy sa vykonávajú zväčša formou testov na rôznych vzorkách obyvatel'stva. Taktiež môže ako indikátor vzdelania poslúžit' aj počet rokov strávených školskou dochádzkou $\mathrm{k}$ predpokladanému počtu rokov, za ktoré by bol jedinec schopný nadobudnút' daný stupeň vzdelania. V rámci indikátorov vzdelania je možné poukázat' aj na stupeň dosiahnutého vzdelania alebo na prístup obyvatel'ov danej krajiny ku vzdelaniu. (Coudouel, Hentschel, Wodon, 2002).

Výdavky verejnej správy na vzdelávanie patrí $\mathrm{k}$ indikátorom chudoby $\mathrm{v}$ rámci dimenzii vzdelania. Finančné čiastky poskytnuté pre školské zariadenia často reflektujú všeobecné bohatstvo danej krajiny. V prípade chudobnejšej krajiny môžeme predpokladat', že tieto náklady budú menšie ako v prípade vyspelej krajiny. To sa samozrejme odzrkadl'uje aj na gramotnosti samotného obyvatel'stva.

Demografické indikátory nám môžu taktiež poslúžit' pre sledovanie chudoby. K hlavným indikátorom chudoby demografickej skupiny ukazovatel’ov patrí vel'kost' a štruktúra domácnosti. Skúma sa vzt’ah medzi vel'kost'ou a zložením domácnosti vo vzt’ahu $\mathrm{k}$ chudobe. Môže íst' taktiež o konkrétnu analýzu jednotlivých členov domácnosti, popr. len o ich vek. Domácnosti ktoré trpia 
chudobou sú zväčša početne väčšie. Chudobnejšie domácnosti sú zložené najmä z počtu členov, ktorí majú mladší vek. K demografickým indikátorom je možné priradit' aj pohlavie (Haughton, Khandker, 2009).

Pohlavie osôb priamo ovplyvňuje, ako demografický indikátor, samotný príjem a možnost' zamestnania sa. Vo všeobecnosti platí, že ženy získavajú menšie príjmy ako muži. Pearce (1978) uvádza, že feminizácia chudoby nastala v USA v 70.-tych rokoch $\mathrm{v}$ dôsledku udržiavania domácností osamelými matkami a vzrastajúcou mierou chudoby.

Chudobu môže indikovat' napr. aj hmotný majetok človeka. Vo všeobecností platí, že čím má osoba viac hmotných statkov, tým je bohatšia. Nemusí to však platit' pri vidieckom obyvatel'stve, kedy má domácnost' nízky príjem a značný majetok. Majetok sa v tomto prípade t’ažko zhodnocuje (Haughton, Khandker, 2009).

Materiálna deprivácia sa taktiež radí medzi indikátory chudoby. OECD (2017) definuje materiálnu depriváciu ako neschopnost' domácnosti dovolit' si služby, ktoré sú typické pre spoločnost' v danom čase, bez ohl'adu na preferencie l'udí k týmto položkám. V Afrike sa stretávame v chudobných oblastiach predmestí $\mathrm{s}$ totálnou materiálnou depriváciou. V lepších prípadoch má osoba, popr. rodina, aspoň nejaké provizórne prístrešie.

\section{Rozšírenie chudoby vo svete}

$\mathrm{V}$ tejto kapitole analyzujeme jednotlivé regióny sveta (Afrika, Amerika, Ázia, Austrália a Oceánia, Európa) z hl’adiska vybraných indikátorov chudoby. Zároveň sa táto kapitola venuje príčinám chudoby v týchto regiónoch. Indikátory, ktoré poskytuje Svetová banka a zároveň sa nimi dá získat' prehl'ad o chudobe vo svete, sú: hrubý priemerný príjem na osobu, nezamestnanost', gramotnost' populácie, hrubá miera úmrtnosti, odhadovaná dížka života pri narodení.

Vzhl'adom na príčiny a dôsledky chudoby sa v minulosti všeobecne hovorilo, že najväčší vplyv na chudobu vo svete má ekonomický rast danej krajiny. Existuje však vel'ké množstvo situácií, ktoré sa priamo podiel'ajú na vzniku tohto nežiaduceho sociálneho javu vo svete. $\mathrm{V}$ literatúre sa stretávame s vel'kým množstvom názorov $\mathrm{v}$ rámci ktorých sa každý autor stavia $\mathrm{k}$ príčinám chudoby trochu iným spôsobom. Dôsledky chudoby d’alej prehlbujú zlé postavenie už chudobných l'udí vo svete a vytvárajú d’alší nekonečný ret’azec negatív.

Hrubý priemerný prijem na osobu je prevedený pomocou parity kúpnej sily na hodnotu medzinárodného dolára (mapa 1). Ten má rovnakú kúpnu silu ako dolár v Spojených štátoch. Tento indikátor je jediné približne objektívne bežné meradlo relatívneho ekonomického bohatstva daného štátu. Avšak aj v rámci tohto indikátora môžeme nájst' zavadzajúce nepresnosti, nakol'ko sa $\mathrm{v}$ úvahu berie celkový priemerný príjem na obyvatel'a. Prvou nevýhodou tejto skutočnosti je, že priemerný príjem nedosahuje každý občan daného štátu. Práve osoby postihnuté 
chudobou nedosahujú $\mathrm{v}$ rozvojových krajinách ani $1,90 \$$ na deň. Naopak najbohatšie obyvatel'stvo daného štátu výrazne ovplyvňuje priemerný príjem svojim osobným vysokým ziskom. Ten, ked' sa spriemeruje s príjmom bežných osôb, často môže hodnotu hrubého príjmu na osobu výrazne zdvihnút'. Taktiež v ňom nie sú brané v úvahu žiadne náklady na život (www.data.worldbank.org, 2017).

Mapa 1: Hrubý priemerný príjem populácie vo svete v roku 2015

Map 1: Gross average income of the population in the world in 2015

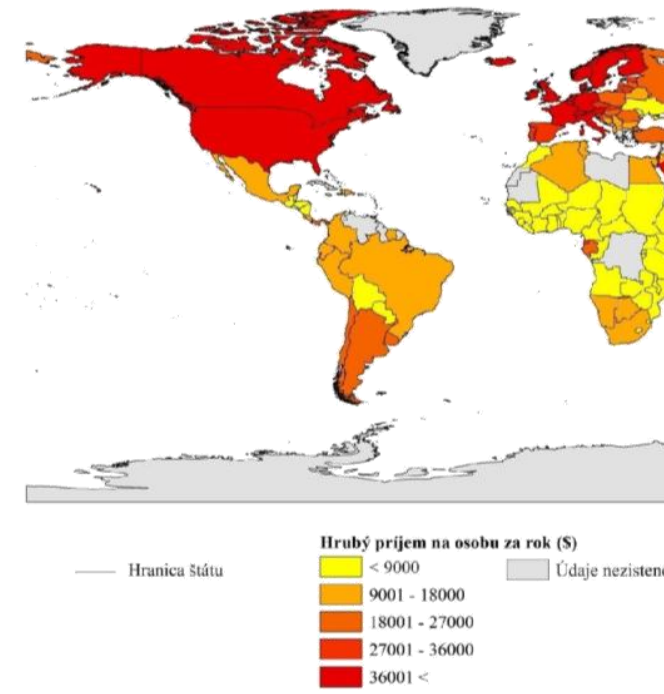

Údaje o hrubom príjme na osobu poskytuje Svetová banka. Najaktuálnejšie spracované údaje sú dostupné za rok 2015. Je nutné aj podotknút', že niektoré štáty tieto štatistiky nevedú už niekol'ko rokov, preto sa v databázach Svetovej banky ani neevidujú.

Nezamestnanost' potenciálne pracujúcich osôb referuje podiel pracovnej sily, ktorá nie je zamestnaná ale je k dispozícií pre hladanie zamestnania (mapa 2). Nezamestnanost' je sama o sebe sociálny jav, ktorý negatívne vplýva na celkovú ekonomickú situáciu daného štátu, nie len na nezamestnaného jednotlivca. Podobne ako pri predchádzajúcom indikátore, aj pri nezamestnanosti sa môžeme stretnút' so zavádzajúcimi údajmi. Skupina obyvatel'ov síce môže byt' v danej krajine zamestnaná, ale jej mzda je nízka. Taktiež osoby, ktoré sú vedené ako nezamestnané môžu pracovat' bez pracovnej zmluvy a tým ovplyvňujú podiel nezamestnaných v krajine (www.data.worldbank.org, 2017). 
Údaje k vypracovaniu je možné nájst' v databázach Svetovej banky. Taktiež ako pri hrubom priemernom príjme na osobu, aj pri tomto indikátore Svetová banka neposkytuje údaje pre všetky štáty, resp. nie za každý rok. Posledné získatel'né a relevantné údaje pre predstavu stavu nezamestnanosti vo svete pochádzajú z roku 2014.

Mapa 2: Nezamestnanost' potenciálnej pracujúcej populácie vo svete v roku 2014 Map 2: Unemployment of potential working population in the world in 2014

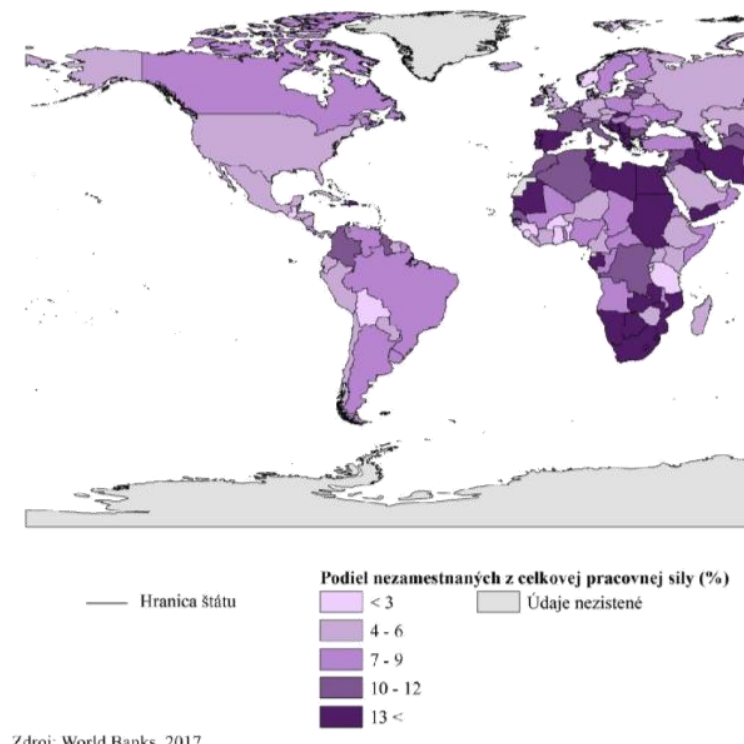

Zdroj: World Banks, 2017

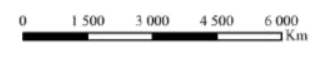

Gramotnost' populácie sa vyjadruje ako percento obyvatel'ov, ktorí môžu s porozumením, čítat' a písat' krátke a stručné vyhlásenia (mapa 3). Všeobecne platí, že gramotnost' taktiež zahŕňa aj počítanie, v tomto prípade to znamená vykonávat' jednoduché aritmetické kalkulácie. Tento ukazovatel' sa vypočíta ako podiel počtu gramotných osôb $\mathrm{k}$ celkovému obyvatel'stvu a vynásobením čísla 100 (\%). Gramotnost' relatívne dobre odzrkadl'uje chudobu, ked'že sa často hodnotí aj prístup ku vzdelaniu, ktorý je $\mathrm{v}$ rozvojových krajinách sveta obmedzený. Gramotnost' je možné rozdelit' d'alej na gramotnost' detí a dospelých a v rámci nich sa d'alej zaoberat' pohlavím, sociálnym statusom a odvetvím gramotnosti, ako napr. finančná gramotnost', mediálna gramotnost', počítačová gramotnost' a pod. Tieto údaje je avšak náročné vyhl'adat' a na webových stránkach Svetovej banky sú poskytnuté len formou grafov bez hmatatel'ných číselných dát (www.data.worldbank.org, 2017).

V prípade tejto práce sú údaje o gramotnosti použité zo štatistických stránok 
Svetovej banky. V databázach Svetovej banky v rámci gramotnosti nachádzame najdetailnejšie údaje o gramotnosti z roku 2015.

Mapa 3: Gramotnost' populácie vo svete v roku 2015

Map 3: Population literacy in the world in 2015

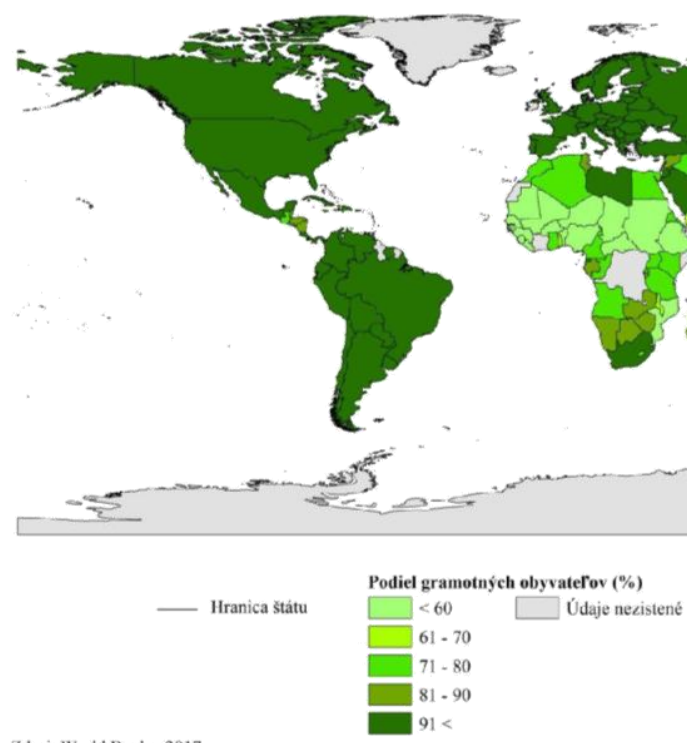

Hrubá miera úmrtnosti je uvedený počet úmrtí na 1000 (\%) obyvatel'ov počas jedného roka (mapa 4). V rámci chudoby sa úmrtnost' uvádza ako faktor, ktorý reflektuje úroveň zdravotnej starostlivosti daného štátu. Nerozvinutejšie časti sveta sú taktiež často krát náchylnejšie na nepokoje, ktoré taktiež so sebou prinášajú úmrtnost' obyvatel'stva. Úmrtnost' sa môže d'alej rozdel'ovat' na úmrtnost' spôsobenú chorobami, úrazmi, užívaním drog, úmrtnost' súvisiacu s pracovnou činnost'ou, úmrtnost' v oblastiach konfliktov a pod. Pre tento fakt ovplyvňuje objektívny obraz v rámci geografickej vizualizácie úmrtnosti vo svete. Úmrtnost' neovplyvňujú len vyššie spomínané príčiny, ale aj prírodné podmienky.

Dáta o úmrtnosti poskytuje Svetová banka na svojich stránkach databáz. Ako v predchádzajúcich údajoch, nie sú poskytnuté údaje pre každý štát. Pre vytvorenie relevantného výstupu sú k dispozícii údaje z roku 2014.

Odhadovaná dľ́̌ka života pri narodení udáva počet rokov, ktoré sa môže osoba dožit' za predpokladu, že sa doterajší stav mortality nezmení počas celej doby jej života. Nevýhodou tohto meradla je, že nepredpokladá že za život daného jedinca sa v krajine, v ktorej žije, neuskutoční žiadna zmena, ktorá by mohla či už 
pozitívne alebo negatívne ovplyvnit jeho život. Neberie v úvahu zmeny politickej ani klimatickej situácii na danom území. Taktiež ale nepredpokladá že daný jedinec môže počas svojho života migrovat'. Všeobecne sa predkladá, že v rozvojových krajinách bude odhadovaná dížka život pri narodení menšia ako v krajinách vyspelých (www.data.worldbank.org, 2017).

Svetová banka $\mathrm{k}$ tomuto indikátoru poskytuje údaje $\mathrm{k}$ roku 2014. Tiež môžeme vidiet', že k niektorým štátom dáta na webovej stránke Svetovej banky dostupné nie sú.

Mapa 4: Hrubá miera úmrtnosti vo svete v roku 2014 Map 4: Gross mortality rate in the world in 2014
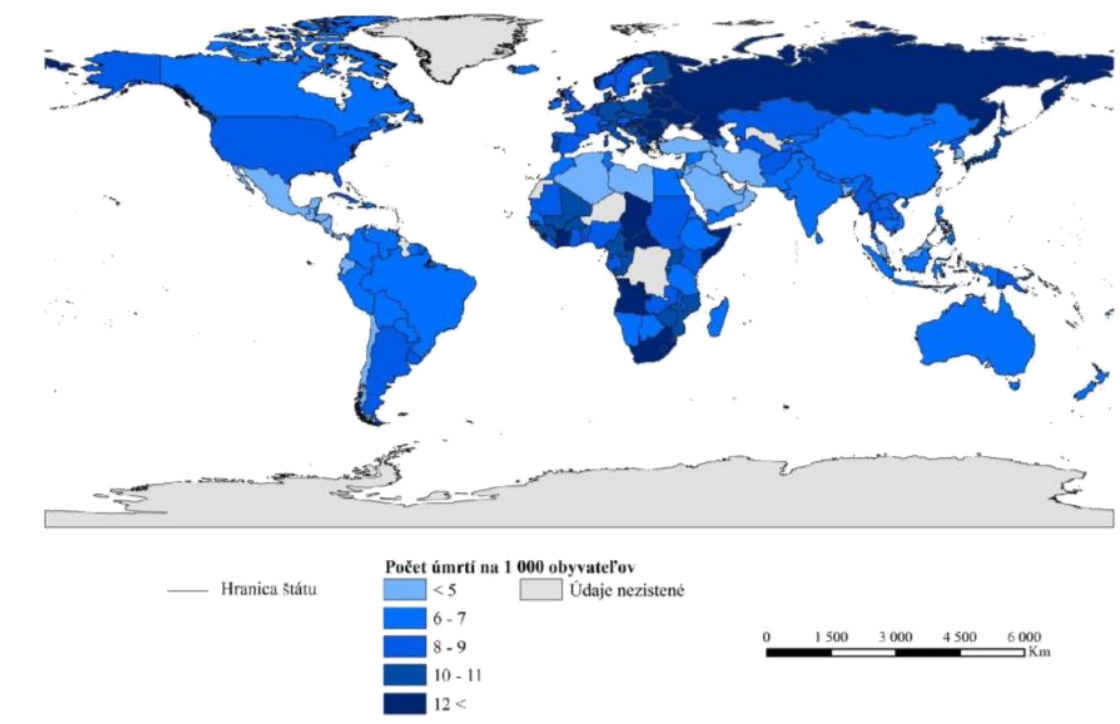

Afrika predstavuje v rámci priemerného hrubého príjmu na osobu za rok región $\mathrm{s}$ najmenšími hodnotami na svete. Obyvatelia štátov severnej a južnej Afriky zarábali najväčšie príjmy z celého územia tohto regiónu, až na štát Gabon. Ten jednoznačne $\mathrm{v}$ príjmoch dominuje. $\mathrm{V}$ roku 2015 tu priemerný hrubý ročný príjem dosahoval 18880 \$ na osobu. Obyvatelia Alžírska zarábali v hrubom príjme priemerne 14310 \$ a obyvatelia Egypta 10710 \$ na osobu v tomto roku. $\mathrm{Na}$ opačnom konci Afriky, v Botswane dosahovala hodnota tohto indikátora 15510 \$ na osobu za rok 2015. Avšak z mapy vidíme, že vel'ká čast' štátov strednej Afriky nedosahuje ani 9000 \$ na osobu za rok v hrubom príjme. Čo je horšie, niektoré krajiny sa tejto hranici ani nebližia. Napr. v Stredoafrickej republike v roku 2015 predstavoval tento indikátor len 620 \$ a v Libérii 720 \$. 
Pri pohl'ade do mapy 2 vieme identifikovat' regióny v Afrike, ktoré sú postihnuté najväčšou nezamestnanostou. Ide hlavne o oblasti južnej Afriky ale taktiež na severozápade. Najvyššie percentuálne podiely nezamestnanosti potenciálne pracujúcej populácie nachádzame $\mathrm{v}$ štátoch, ako napr. Líbya $\mathrm{s}$ takmer $20 \%$ podielu nezamestnaných. V Sudáne sa taktiež stretávame s vel'kou nezamestnanost'ou. Tu predstavuje percentuálny podiel nezamestnaných 14,8\%. Ešte väčší podiel nezamestnanosti, až 25,1 \%, lokalizujeme v štáte Južná Afrika ale taktiež vo Svazijsku $(22,3 \%)$.

$\mathrm{S}$ vel'kým podielom negramotného obyvatel'stva sa stretávame v subsaharskej Afrike (mapa 3). V štátoch ako Čad, Sudán, Niger či Mauritánia sa stretávame s podielom gramotnosti obyvatel'stva menšou ako $60 \%$. V štáte Niger hodnota tohto indikátora predstavovala len $19,1 \%$. V Čade v roku 2015 predstavoval podiel gramotných obyvatel'ov menej ako polovica populácie štátu, a to 40 \%. Naopak najvyššiu gramotnost' obyvatel'stva sledujeme v Líbyi $(91,4 \%$ ) a Južnej Afrike (94,6 \%).

Z geografického hl'adiska vieme podl'a mapy 4 určit' štáty Afriky s najväčšou hrubou mierou úmrtnosti. Vidíme, že priestorové rozloženie úmrtnosti je $\mathrm{v}$ tomto regióne fragmentovité. V strednej Afrike sú to napr. štáty, ako Čad s hrubou mierou úmrtnosti 14,06 \%o alebo Stredoafrická republika s mierou 14,53\%o úmrtí. Na východnom pobreží Afriky vidíme Somálsko, ktoré ma taktiež vel'kú hrubú mieru úmrtnosti, a to $12,04 \%$. V južnej časti regiónu sa stretávame s najvy̌̌šou úmrtnost'ou v štáte Južná Afrika. Tu v roku 2014 hrubá miera úmrtnosti predstavovala hodnotu $12,46 \%$. V ostatných častiach Afriky sú tieto hodnoty menšie.

Odhadovaná dížka života pri narodeni pre regióny Afriky dosahuje najnižšie hodnoty $\mathrm{v}$ rámci celého sveta. Jediné štáty, ktoré zaznamenávajú viac rokov odhadovanej dížky života pri narodení sú: Maroko, Alžírsko a Tunisko, čiže štáty na severe Afriky. Vo všetkých troch štátoch predstavuje odhadovaná dížka života pri narodení približne 74 rokov. Najnižšś odhadovaný vek vidíme v regiónoch centrálnej Afriky, $\mathrm{v}$ štátoch juhovýchodného pobrežia a taktiež na západe Afriky. V rámci štátov centrálnej Afriky môžeme uviest' napr. Kamerun. V roku 2014 tu predstavoval najvyšší odhadovaný vek obyvatel'ov pri narodení 55 rokov. Mozambik sa nachádza na juhovýchodnom pobreží Afriky. Ani tu nie je odhadovaná dížka života príliš vysoká, taktiež len 55 rokov. Z oblastí západného pobrežia Afriky nám môže ako príklad poslúžit' Pobrežie Slonoviny. Odhadovaná dížka života pri narodení je rovná 51 rokov (www.data.worldbank.org, 2017).

Za jednu z hlavných príčin chudoby $\mathrm{v}$ Afrike môžeme označit' konflikty. Predpokladalo by sa, že väčšina ozbrojených konfliktov ako vojny alebo len malé štátne prevraty majú za účel obohatenie akýmkol'vek bohatstvom alebo územím. Logicky by sme mohli tvrdit', že l'udia budú bojovat' za územie, politickú moc, za svoje práva alebo podobné veci. Avšak v skutočnosti väčšina konfliktov sú vel'mi nákladné udalosti, ktoré už chudobnú krajinu uvrhnú $v$ ešte väčšiu chudobu. V 
nedávanej dobe africké štáty zažili mnoho občianskych vojen, povstaleckých nepokojov a teroristických útokov. Za najväššie fatálne konflikty v tejto oblasti v posledných desat'ročiach môžeme považovat' občiansku vojnu v Somálsku v rokoch 1991 až 1993, konflikt v Dárfúre na území Sudánu, ktorý začal v roku 2003 a v podstate pokračuje do dnešných dní alebo vyčíňanie teroristickej skupiny Boko Haram, ktorá terorizuje obyvatel'ov štátov Niger, Nigéria, Čad a Kamerun od roku 2009 po súčasnost'. Problémom v týchto regiónoch je hlavne stále sa opakujúca napätá situácia kvôli nízkym príjmom a tak sa z konfliktov v tejto oblasti stáva pasca (Collier, 2009).

Ďalším problémom, ktorý podporuje vznik chudoby v Afrike je geografická poloha. Za jeden $\mathrm{z}$ hlavných geografických faktorov môžeme považovat' klimatické pomery. Zatial' čo štáty $\mathrm{s}$ priaznivými klimatickými pomermi lokalizované viac na sever, resp. na juh od rovníka sú na tom ekonomicky lepšie, štáty $\mathrm{v}$ tropickom a subtropickom pásme trpia hlavne $\mathrm{v}$ posledných rokoch enormnými obdobiami sucha. Nakol'ko vel'ké množstvo z týchto krajín je závislé hlavne na pol'nohospodárstve, práve pre nepriaznivé klimatické podmienky je takmer nereálne tu dopestovat' taký objem potravín, ktorý by nasýtil už tak vel'ký počet obyvatel'ov. Výsledkom je vyplienenie základných prírodných zdrojov, degradácia pôdy a celého životného prostredia. Najhoršie sú na tom štáty ako Etiópia, Čad, Sudán a Somálsko, kde denne umiera vel'ký počet l'udí na podvýživu (Landes, 2004).

Vládne zlyhanie je taktiež významná príčina chudoby v Afrike. Vláda by mala pomocou správnej politiky zlepšovat' ekonomickú a sociálnu úroveň krajiny a realizovat' jej možnosti pre vývoj. Ak vláda nevytvára priaznivý priestor pre rozvoj, nemá zdroje potrebné pre vytvorenie dostatočnej infraštruktúry, vyberá príliš nízke alebo naopak vysoké dane, chcene alebo nechcene zvyšuje štátny dlh, nezaist'uje $\mathrm{v}$ tomto smere ani štandardné sociálne služby a neudržuje stabilitu a bezpečnost' v krajine. V štátnom sektore $\mathrm{v}$ Afrike $\mathrm{v}$ niektorých štátoch prevláda aj vysoká miera korupcie. Tieto okolnosti môžu viest' už $\mathrm{k}$ vyššie spomínaným štátnym prevratom. Štátny predstavitelia sa snažia takýmto konfliktom zamedzit' akýmikol'vek prostriedkami a to má za následok vznik diktátorských režimov. Príklady je možné v rámci Afriky vidiet' vo väčšine štátov (Collier, 2009). Najzávažnejším prípadom je napr. Omar al-Bašír, ktorý patrí bez pochýb medzi najhorších prezidentov Afriky. Pripisuje sa mu práve Darfúrska genocída $\mathrm{v}$ Sudáne. Bol na neho vydaný zatykač za jeho vojnové zločiny Medzinárodným trestným súdom. Ďalším príkladom môže byt' Teodoro Obiang Mbasogo, prezident Rovníkovej Guinei. Aj ked' je tento štát relatívne malý a má vysoké HDP na obyvatel'a (21 000 \$), $70 \%$ l’udí žijúcich v ňom žije pod hranicou chudoby. Mbasogo je totižto najdlhšie vládnuci diktátor súčasnosti. V štáte si drží moc a drvivú väčšinu bohatstva už od roku 1979. V tejto krajine je katastrofálne rozvinutá infraštruktúra, biedne zdravotníctvo a školstvo (www.africaw.com, 2017). 
Chudobu v Afrike taktiež môžeme pripísat' demografii. Chudobné rodiny mávajú zväčša väčší počet detí. Náklady, ktoré sú spojené s uživením tol'kých potomkov, nie sú väčšinou rodiny v Afrike schopné pokryt'. Vidiecke rodiny $\mathrm{v}$ Afrike chcú mat' vel'ký počet detí, hlavne kvôli faktu, že potrebujú pracovnú silu kvôli obrábaniu vlastných pozemkov.

Poslednou významnou príčinou v Afrike je nezamestnanost', resp. skrytá nezamestnanost'. Problém, kvôli ktorému nie je možné vyriešit' zlý ekonomický stav obyvatel'ov, je neschopnost' nájst' si zamestnanie. Podniky nie sú schopné vytvorit' taký počet pracovných miest, aký je po nich dopyt. Títo l'udia často krát pracujú „na čierno“ v zlých pracovných podmienkach, kde sú zamestnávatel’om vykorist'ovaní.

Historickou príčinou chudoby v Afrike je kolonializmus. V 19. storočí boli hranice afrických krajín nastolené bez bližších geografických či historických analýz. Mocnosti z Európy, ktoré si tieto africké krajiny podrobili mnoho krát spojili znepriatelené kmene alebo naopak rozdelili kmene, ktoré mali medzi sebou dlhotrvajúce a pevné väzby. Easterly a Levine (1997) tvrdia, že problémy na Africkom kontinente sú z vel'kej miery spôsobené vel'kou etnicitou obyvatel'stva.

V Amerike najvyššie hrubé príjmy dosahujú obyvatelia severných regiónov Ameriky (mapa 1). V roku 2015 v Spojených štátoch amerických predstavoval priemerný hrubý príjem na osobu $57540 \$$ za rok. V Kanade bola hodnota tohto indikátora $\mathrm{v}$ tomto roku o niečo menšia, a to $43900 \$$. O $1 / 2$ nižšie priemerné príjmy dosahovali obyvatelia štátov na opačnom konci tohto svetadiela. Napr. $\mathrm{v}$ Čile hodnota priemerného hrubého ročného príjmu bola 22760 \$ a v Argentíne 20 010 \$ na osobu. Nasledujú štáty severných regiónov južnej Ameriky a Mexiko. V Mexiku k roku 2015 zarábala v hrubom priemere jedna osoba za rok 16860 \$. Pri pohlade na Brazíliu už táto hodnota bola o čosi menšia, a to 15050 \$. Z geografického hladiska najmenšie príjmy nachádzame $\mathrm{v}$ štátoch centrálnej časti južnej Ameriky. V Paraguaji predstavoval v roku 2015 hrubý príjem na osobu 8 $680 \$$ za rok, zatial' čo v Bolívii to bolo len 6710 \$. Zo štátov strednej Ameriky môžeme uviest' Honduras s priemerným hrubým príjmom 4750 \$ na jedného obyvatel'a. Z oblasti Karibiku môžeme uviest' Haiti, kde je hodnota tohto indikátora žalostne nízka, a to len 1760 \$.

V štátoch Ameriky sa stretávame s menším podielom nezamestnanosti ako $\mathrm{v}$ Afrike. S najväčšími hodnotami sa stretávame v severných regiónoch južnej Ameriky. V Kolumbii v roku 2014 dosiahla miera nezamestnanosti podiel 10,1\% potenciálne pracujúceho obyvatel'stva. V Guyane predstavoval podiel nezamestnanosti presne o $1 \%$ viac ako $\mathrm{v}$ Kolumbii. V ostatných štátoch Amerického svetadielu nedosahujú podiely nezamestnanosti vel'ké číselné hodnoty. Môžeme uviest' napr. Spojené štáty, kde v roku 2014 podiel tohto negatívneho javu predstavoval $6,2 \%$.

$\mathrm{V}$ rámci priestorovej diferenciácie gramotných obyvatel'ov v Amerike v 
mape 3. vidíme, že drvivá väčšina týchto štátov dosiahla v roku 2015 viac ako 91 \% podiel. Najmenšie podiely gramotnej populácie vidíme $\mathrm{v}$ štátoch strednej Ameriky, ako napr. Guatemala s podielom 79,1 \% gramotných obyvatel'ov.

$\mathrm{V}$ regiónoch Ameriky vidíme v mape 4 relatívne malé hodnoty hrubej miery úmrtnosti. Paradoxne jednu z najvyšších mier vidíme práve v Spojených štátoch. V roku 2014 tu hodnota tohto indikátora dosahovala 8,1\%o. Na opačnom konci svetadielu, v Argentíne, sledujeme taktiež vysoké hodnoty tohto ukazovatel'a, a to 7,57 \%o. Vyššie miery úmrtnosti tu má za príčinu nižšia pôrodnost'. To má za následok starnutie populácie $\mathrm{v}$ týchto štátoch. Niektoré ostrovné štáty Karibiku dosahujú taktiež vyššiu mieru úmrtnosti. Napr. na Haiti v roku 2014 bola zaznamenaná hrubá miera úmrtnosti 8,71\%o.

Vo väčšine štátov Ameriky pozorujeme relatívne vysokú odhadovanú dĺžku života pri narodení. V Kanade a v Čile predstavuje tento indikátor hodnotu 81 rokov $\mathrm{k}$ roku 2014. O čosi menej odhadovaných rokov života zaznamenávame $\mathrm{v}$ USA, a to 78 rokov. Odhaduje sa, že o 4 roky menej ako v Spojených štátoch sa dožije osoba, ktorá sa narodí v Brazílii. Najmenšie hodnoty tohto indikátora sledujeme v centrálnej časti južnej Ameriky pri štátoch Paraguaj (72 rokov) a v Kolumbii o rok viac (www.data.worldbank.org, 2017).

Za hlavnú príčinu chudoby v Amerike sa pokladá podobne ako pri prípade Afriky vládne zlyhanie. Ako príklad môžeme uviest' napr. Augusta Pinocheta, ktorý v Čile vládol po dobu 20 rokov. Aj ked' sa hovorí, že tento diktátor môže za podstatný rozvoj Čile, za svojej vlády dal zabit' množstvo nevinných mužov a žien. Chudoba v južnej Amerike môže podobne, ako v Afrike, viest' ku politickej nestabilite a straty verejnej bezpečnosti. Ohlásit' zločin $v$ oblastiach strednej a južnej Ameriky je často nebezpečné, pretože polícia býva skorumpovaná a môže spolupracovat' priamo so zločincami (www.thoughtco.com, 2017).

V oblastiach Ameriky nie sú až také výrazné konflikty ako v Afrike či Ázií. Najväčší ozbrojený konflikt $\mathrm{v}$ posledných desat'ročiach, ktorý mal vplyv na rozšírenie biedy v týchto oblastiach, predstavuje Mexická drogová vojna, ktorá začala v roku 2006 a ku dnešnému dňu si vyžiadala cez 93000 obetí. Tento konflikt mal vplyv nielen na obyvatel'stvo Mexika, ale aj Spojených štátov. Môžeme teda tvrdit', že v Amerike majú vplyv na chudobu obyvatel'stva aj $\underline{d r o g y}$ (www.edition.cnn.com, 2013).

Geografická poloha sa taktiež ako pri Afrike považuje za jednu z najhlavnejších príčin chudoby $\mathrm{v}$ Amerike. $\mathrm{V}$ tejto časti sveta sa obzvlášs' stretávame hlavne v Južnej Amerike s geografickými problémami súvisiacimi s chudobou. Chudoba v Južnej Amerike sa hlavne spája s obyvatel'mi žijúcimi v mestách, v ktorých je viac ako $70 \%$ populácie. Tento stav má za následok urbanizácia. Avšak sa často stretávame aj s domorodými rol'níkmi na vidieku, ktorí sú paradoxne ešte chudobnejší. Ked’že sa neprest'ahovali do miest musia si potravu často krát dopestovat' sami. Ked'že v odl'ahlých oblastiach je len málo pracovných príležitostí, sú títo l'udia nútení využit' každú príležitost'. Dobrým príkladom je 
napr. baňa San Cristobal v Bolívií, kde baníci pracovali za nízke mzde v tažkých podmienkach. $\mathrm{V}$ dnešných dňoch sa tu stále používajú len krompáče a lopaty. Strieborné doly $\mathrm{v}$ Bolívií vzali život približne 8 miliónom l'ud’om. Jedným z dôvodov je aj odl'ahlost' lokalít $\mathrm{v}$ horách alebo pralesoch, kde títo l'udia žijú (www.sumitomocorp.co.jp, 2017)

Kolonializmus, podobne ako pri Afrike, má aj v Amerike svoje opodstatnenie ako príčina chudoby v niektorých oblastiach. Rozvoj brzdila hlavne nadvláda Španielska a Portugalska v minulosti.

V Spojených štátoch sa považujú za najväčšiu príčinu chudoby zvyšujúce sa náklady na zdravotnú starostlivost' a ostatné služby, ako napr. školstvo. Taktiež malá ponuka pracovných miest hrá svoju úlohu v rozšírení chudoby v celej Amerike, nie len Spojených štátoch. Dôsledok drahej zdravotnej starostlivosti má za následok zhoršenie zdravotného stavu obyvatel'stva, čo vedie $\mathrm{k}$ nižším pracovným výkonom. Nákladné školstvo vedie k negramotnosti obyvatel'stva, a to následne k nižšiemu počtu kvalifikovanej pracovnej sily. Nízke mzdy spojené s nedostatkom pracovných miest, drahým školstvom a zdravotnou starostlivost'ou môžu vyústit' ku zvýšenej kriminalite.

V samotných Spojených štátoch amerických neznamená chudoba to isté ako napr. chudoba v Afrike. $70 \%$ chudobných amerických rodín má auto, $97 \%$ má televíziu a priemerný dom takejto rodiny má 4 izby. V Spojených štátoch žije asi len $3 \%$ populácie, ktorá reálne trpí chudobou - títo l'udia nemajú čo jest', kde bývat' a čo si obliect' (www.virtually.cz, 2017).

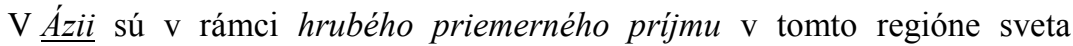
priepastné rozdiely. V oblasti Perzského zálivu nájdeme, štáty ako Qatar, kde tento indikátor v roku 2015 dosahoval rekordných 138400 \$ na osobu za rok. Spojené arabské emiráty (70 020 \$ na osobu) a Saudská Arábia (54 840 \$ na osobu) taktiež predstavujú štáty s vysokou hodnotou priemerného hrubého príjmu za rok. Tieto štáty vd'ačia svojim vysokým príjmom hlavne t’ažbe ropy. Značné priemerné príjmy na osobu však ešte nemusia znamenat' nízku úroveň chudoby. Vysoké hodnoty si môžeme všimnút' taktiež v Japonsku, kde v roku 2015 dosahoval hrubý priemerný príjem 42310 \$ na obyvatel'a za rok. V Japonsku vysoké príjmy možno odôvodnit' vyspelost'ou tohto štátu. Za týmito štátmi nasledujú v hodnotách tohto indikátora regióny centrálnej Ázie, napr. Kazachstan s 23480 \$ na osobu za rok alebo na západe Ázie Turecko s 19740 \$. O niečo menší hrubý príjem na osobu vidíme v Č́ne, kde v roku 2015 predstavoval 14390 \$. Štáty, ktoré majú najmenšie hodnoty tohto meradla sa nachádzajú zväčša v južnej Ázii alebo sa jedná o ostrovné krajiny. Najlepším príkladom je India, kde v roku 2015 obyvatelia priemerne v rámci hrubého príjmu zarábali $6030 \$$. Z ostrovných štátov môžeme uviest' Filipíny s 8940 \$ na osobu ročne.

Pri pohl'ade do mapy 2 vidíme regióny Ázie, ktoré sú najviac postihnuté nezamestnanostou. Najväčší podiel nezamestnanosti lokalizujeme v štáte Jemen, a 
to 17,4 \%. O čosi menšie podiely nezamestnaných lokalizujeme v štátoch Irak, kde podiel nezamestnanosti dosiahol v roku 2014 až 16,4 \% populácie. Nasleduje ho Irán s 12,8 percentuálny podielom nezamestnanosti. V ostatných regiónoch Ázie nepredstavuje nezamestnanost' také vysoké podiely. Naopak $\mathrm{s}$ malými percentuálnymi podielmi sa stretávame v juhovýchodnej Ázii. Napr. v Laose predstavuje podiel nezamestnaných osôb len 1,4\% obyvatel'stva tohto štátu. Dôvod vysokej zamestnanosti $\mathrm{v}$ týchto štátoch je hlavne ich lacná pracovná sila. Tunajšie obyvatel'stvo vykonáva prácu aj za malé finančné zárobky a to do týchto regiónov láka rôznych investorov.

Grafická vizualizácia podielu gramotných obyvatel’ov v Ázii (mapa 3) nám predkladá obraz o priestorovej štruktúre tohto javu. Vidíme, že regióny $\mathrm{s}$ najmenším podielom gramotných osôb sa rozprestierajú $\mathrm{v}$ oblasti Indického subkontinentu. Najmenší podiel gramotnosti má štát Afganistan, a to len 38,2\%. Nasleduje ho Pakistan s o čosi väčším podielom gramotnosti $56,4 \%$, čo aj tak predstavuje malý podiel. Samotná India dosahuje 72,2 percentný podiel vzdelanosti. Zo štátov Ázie ešte môžeme vidiet' relatívne malý podiel gramotnosti napr. v Jemene predstavoval podiel gramotnosti v roku 2015 len 69,9 \%. Pri pohl'ade na ostatné krajiny Ázie pozorujeme naopak vysoký podiel gramotnosti takmer pri všetkých nad $90 \%$.

V rámci hrubej miery úmrtnosti v regiónoch Ázie nie je vel'a štátov, ktoré presahujú túto mieru o viac ako $12 \%$ (napr. Gruzínsko). Najväčšie hodnoty tejto miery môžeme pozorovat' v štátoch juhovýchodnej Ázie. V Mjanmarsku v roku 2014 predstavovala hodnota tohto indikátora 8,25 \% a v susednom Thajsku 7,91 \%o. paradoxne $\mathrm{v}$ štátoch kde by sme predpokladali vysokú mieru úmrtnosti, ako napr. v Sýrii, sú tieto hodnoty relatívne malé - 5,66 \%o. Nízke hodnoty úmrtnosti môžeme aj napriek nižšiemu rozvoju zdravotníctva a konfliktom v niektorých oblastiach pripisovat' vel'kej miere pôrodnosti.

Z pohl'adu odhadovanej dĺžky života pri narodení sa Japonsko zarad'uje na prvé miesto v Ázii. V roku 2014 bol odhad dížky života 83 rokov.

Relatívne vysoké hodnoty počtu dožitých rokov pri narodení zaznamenávame aj v Č́ne (75 rokov), Turecku (75 rokov), či Saudskej Arábii (74 rokov). Naopak nízku odhadovanú dížku života zaznamenávame napr. v Turkmenistane, kde v roku 2014 nadobúdal tento indikátor hodnotu 65 rokov alebo $\mathrm{v}$ Afganistane, kde bol počet rokov ešte o 5 menší ako $\mathrm{v}$ predchádzajúcom prípade (www.data.worldbank.org, 2017).

Za najväčší problém v štátoch Ázie, ktorý je priamo spojený s chudobou je vládne zlyhanie. Ako už bolo popísané pri Afrike a Amerike, zlá vláda má za následok nepriaznivú situáciu v krajine a tá môže vyvrcholit' bud' k diktátorským režimom alebo hromadným povstaniam a nepokojom. Jednoznačným príkladom chudoby v Ázii zapríčineným vládou je Kórejská l’udovodemokratická republika. Je považovaná za jednostrannú totalitnú diktatúru. Väčšina pracovníkov zarába 2 až $3 \$$ za mesiac. Životná úroveň sa zhoršila na extrémnu úroveň deprivácie. 
Priemerná dížka života klesla od roku 1980 o viac ako 5 rokov. Aj ked' je tu vysokú úroveň chudoby odhaduje sa, že Kim Čong Un - hlava štátu, zdedil po svojom otcovi, Kim Čong Ilovi, viac než 4 miliardy \$. Navyše krajina trpí tzv. epidémiou metamfetamínu. Výroba drogy sa využíva ako stimul ekonomiky. Vel'ké množstvo l'udí v tejto krajine (odhaduje sa až 40 \%) sú závislí na tejto droge (www.borgenproject.org, 2017). Dalším príkladom môže byt' Baššár al-Asad, sýrsky prezident, ktorý vládne v krajine od roku 2000. V roku 2007, kedy mali byt' prezidentské vol'by, zostal al-Asad bez opozície ked’že za pomoci svojej tajnej polície dal zatknút', umučit' a zabit' všetkých ostatných politických aktivistov (www.thoughtco.com, 2017).

Konflikty taktiež spôsobujú chudobu v Ázii. V Ázii v posledných desat'ročiach prebehlo najviac vojen vo svete. Najfatálnejším konfliktom je vojna $v$ Afganistane, ktorá sa začala $\mathrm{v}$ roku 1978 a nepokoje stále trvajú dodnes. Táto udalost' dala podnet na vznik teroristickej skupiny - Al-Kaída (Dowling, 2015). Ďalšou vojnou v Ázií bola vojna v Iraku, ktorá začala v roku 2003 a formou občianskych nepokojov pretrváva dodnes. Zo súčasnosti je dôležité spomenút' vojnu v Sýrii. Všetky tieto a mnoho d’alších konfliktov v Ázií majú za následok biedu miestneho obyvatel'stva (www.syriahr.com, 2017).

Taktiež, ako v predchádzajúcich prípadoch, aj v Ázií sa stretávame s geografickou polohou ako jednou z príčin chudoby. Väčšina l'udí ovplyvnených prírodnými katastrofami žije vo východnej a juhovýchodnej Ázii. Časté sú tu hlavne silné záplavy (India, Čína, Bangladéš, Filipíny, Thajsko, Vietnam a Pakistan). Č́nu trápia aj obrovské suchá a vysoké teploty. Odl'ahlost' od miest a členitost' reliéfu je taktiež významným geografickým činitel'om chudoby, ked’že výrazne ovplyvňuje migráciu (Mydlová, Tolmáči, 2013).

Medzi významné príčiny chudoby v Ázií patrí rast cien potravín a cien ropy. Svetové ceny potravín od roku 2011 konštantne stúpajú. V mnohých Ázijských krajinách sa to prejavilo zvýšením inflácie potravín. Ako príklad môžeme použit' Singapur a Južnú Kóreu. Zatial' čo Singapur je na cenu potravín vel'mi citlivý, kvôli faktu, že štát musí drvivú väčšinu potravín dovážat', Južná Kórea si s touto situáciou môže poradit' bez väššieho problému. Kvôli rastom cien potravín a ropy by mohlo do budúcna dôjst' k ekonomickému poklesu krajín.

Austrália a Oceánia v rámci priemerného hrubého príjmu dosahuje vysoké hodnoty. Najvyššie sú v Austrálii - 45320 \$ na osobu a na Novom Zélande - 36 $150 \$$ na osobu. Ostatné ostrovné štáty dosahujú podstatne nižšie hodnoty tohto indikátora. Štáty ako Fiji či Šalamúnove ostrovy nedosahujú ani hodnotu 9000 \$.

V Austrálii a na Novom Zélande vidíme približne rovnaký podiel nezamestnanosti (mapa 2). V oboch štátoch sa stretávame s 5,5\% až $6 \%$ nezamestnanost'ou. $\mathrm{V}$ ostrovných štátoch Oceánie vidíme paradoxne ešte menšie hodnoty podielu ako pri Austrálii a Novom Zélande. Napr. na Šalamúnových ostrovoch predstavuje podiel nezamestnaných osôb len 3,9 \%. 
Austrália a Oceánia sú vzhl'adom na podiel gramotnosti podobne, ako Amerika, jednotné. Austrália dosahuje 99,8\% a Nový Zéland 99,5\% podielu gramotných osôb. V ostrovných štátoch je situácia o niečo horšia. Ako príklad nám môže poslúžit' ostrovný štát Vanuatu, kde v roku 2015 predstavoval podiel gramotnosti osôb $85,1 \%$.

V oblasti Tichomoria sa hrubá miera úmrtnosti pohybuje v normálnych hodnotách. Pre príklad v Austrálii k roku 2014 vidíme hodnotu 6,5 \%o. Na Novom Zélande je táto hodnota podobná, a to $6,88 \%$.

Austrália spolu s Nový Zélandom sa radia $\mathrm{k}$ štátom sveta $\mathrm{s}$ vysokým odhadovaným vekom dožitia sa pri narodení. V Austrálii predstavuje tento vek číselná hodnota 82 rokov a pri Novom Zélande to je 81 rokov. V prípade ostrovných štátov sa táto veková hranica odhaduje na niečo cez 70 rokov (www.data.worldbank.org, 2017).

Medzi hlavné príčiny chudoby v Austrálii patrí demografia. V Austrálií žije v rodinách s 3 a viac det'mi až polovica chudobných detí. Pôrodnost' mladých nevydatých matiek taktiež vplýva na výskyt chudoby v Austrálií. Až 731300 detí mladších ako 15 rokov žilo v roku 2016 pod hranicou chudoby. Podobná situácia vládne aj na Novom Zélande (www.acoss.org.au, 2017).

Stav v štátoch Oceánie nie je všeobecne spájaný s pojmom chudoba. Tichomorské krajiny často o sebe samých nehovoria ako o chudobných. Namiesto toho používajú pojem „hardship - t’ažkosti“. V Oceánii sa nedá hovorit’ o bežnej chudobe. O problémoch chudoby spojenej s hladom sa v tej oblasti nedá hovorit'. Cítit' tu však klesajúcu úroveň l'udského rozvoja $\mathrm{v}$ mnohých častiach regiónu. Vzhl'adom na to, že $90 \%$ populácie Oceánie žije v rurálnych podmienkach a zároveň $90 \%$ vidieckeho obyvatel'stva pocituje vyššie uvedené „t’ažkosti“, môžeme povedat', že chudoba tu je predovšetkým vidiecky problém. Preto d’alším problémom zapríčiňujúcim chudobu v regióne Austrálie a Oceánie je spoločenský rozvoj.

O konfliktoch či zlyhaní vlády sa $\mathrm{v}$ tunajších podmienkach hovorit’ nedá. Štáty v ktorých boli zaznamenané v minulosti menšie nepokoje sú Fiji, Papua Nová Guinea a Šalamúnove ostrovy. Kvôli vel'kým vzdialenostiam medzi ostrovmi môžeme skôr hovorit' o geografickej polohe, ako o faktore, ktorý tu môže ovplyvňovat' mieru chudoby. Nie každý z ostrovov má dostatok vlastných zdrojov pre obživu obyvatel'stva. L'udia, ktorí cestujú kvôli nepriaznivej situácii do iných krajín alebo do rozvinutejších regiónov v rámci svojho štátu, často krát upadajú v mestskom prostredí ešte do väčšej chudoby, nakol'ko sa nevedia prispôsobit' životu v mestách (www.ruralpovertyportal.org, 2017).

V Európe priemerný hrubý príjem dosahuje najvyššie hodnoty prevažne $\mathrm{v}$ západných a severných štátoch. Nemecko v roku 2015 dosiahlo v priemere 49090 $\$$ na osobu v rámci hrubého príjmu. Smerom na sever, sa stretávame s Nórskom, kde bol v tomto roku hrubý príjem ešte väčší, a to $65430 \$$ na osobu. O niečo 
menšie príjmy sledujeme v centrálnejších regiónoch Európy. Napr. v Slovinsku sa stretávame s hodnotou 31180 \$ na osobu za rok a v Pol'sku s 25930 \$. Pobaltské štáty a Rusko dosahujú v priemere od $20000 \$$ do $30000 \$$ na osobu v rámci hrubého ročného príjmu. Nižšie príjmy indikujeme na Balkáne, kde napr. v Bosne a Hercegovine l'udia $\mathrm{v}$ hrubom príjme priemerne zarábajú $10900 \$$ za rok. Najhoršia situácia, čo sa týka hrubého priemerného príjmu v Európe je na Ukrajine (7 840 \$ na osobu) a v Moldavsku (5 400 \$ na osobu).

$\mathrm{Z}$ priestorového hl'adiska sa $\mathrm{v}$ Európe stretávame $\mathrm{s}$ relatívne odlišným geografickým rozložením nezamestnanosti, ako tomu bolo v prípade príjmov. $\mathrm{S}$ najväčším podielom sa stretávame pri balkánskych štátoch. V roku $2014 \mathrm{v}$ Bosne a Hercegovine dosiahol podiel nezamestnanosti až 27,9 \%. Nasleduje Srbsko s 22,2 percentnou nezamestnanost'ou obyvatel'stva. Vel'ké hodnoty vidíme aj v oblasti Pyrenejského polostrova - v Španielsku (24,7 \%) a Portugalsku (14,2 \%). Taktiež v Grécku sledujeme vysoký podiel nezamestnanosti.

$\mathrm{V}$ celej Európe sa $\mathrm{v}$ rámci gramotnosti stretávame s viac ako $90 \%$ podielom gramotných obyvatel’ov v každom štáte. Pri väčšine členských štátoch Európskej únie dokonca tento podiel predstavuje viac ako $98 \%$.

V Európe sa stretávame s prekvapivo vysokými mierami hrubej úmrtnosti. Odôvodnit' tento stav môžeme kvôli starnutiu Európy. Znamená to, že sa v štátoch Európy $\mathrm{v}$ súčasnosti rodí menej detí. Vysokú úmrtnost' lokalizujeme v štátoch Balkánskeho polostrova, Pobaltia, na Ukrajine, v Moldavsku a Rusku. Ako príklad zo štátov Balkánu s vysokou mierou hrubej úmrtnosti môžeme uviest' Srbsko. Tento štát v roku 2014 dosahoval úmrtnost' 14,2 \%o. V Lotyšsku, ktoré sa zarad'uje k pobaltským štátom, predstavovala táto miera 13,7 \%o úmrtnosti. Najvyššiu mieru úmrtnosti v Európe dosiahla v roku 2014 Ukrajina, a to 14,7 \%o.

V štátoch západnej Európy pozorujeme vysoké odhadované dížky života obyvatel’ov pri narodení. V celej západnej, juhozápadnej a strednej Európe pozorujeme pri štátoch hodnoty odhadovanej dížky života 80 a viac rokov. V strednej Európe a na balkánskom polostrove už ale sledujeme o čosi nižšie údaje. Napríklad v Mad'arsku predstavovala v roku 2014 odhadovaná dížka života jedinca po narodení 75 rokov. V Litve táto hodnota bola presne o 1 rok menej. Najnižší odhadovaný vek pozorujeme v štátoch východnej Európy, konkrétne najnižšiu na Ukrajine - 71 rokov (www.data.worldbank.org, 2017).

V rámci štátov Európy sa nedá hovorit' o chudobe spôsobenej geografickou polohou. Aj ked’ niektoré štáty nemajú práve významnú geografickú polohu, všetky štáty Európy sú dostatočne rozvinuté vzhl'adom na tento faktor.

$\mathrm{V}$ rámci konfliktov, ako jednej z príčin chudoby, sa v Európe stretávame $\mathrm{v}$ minulosti s občianskou vojnou v bývalej Juhoslávií, ktorá začala v roku 1991 a trvala až do roku 2001. Jej dopad cítit' v štátoch na Balkáne ešte v súčasnosti a dodnes je tu cítit' napätie. Konflikt bol vyvolaný kvôli etnickej a náboženskej rôznorodosti obyvatel'stva ale taktiež $\mathrm{v}$ ňom hrali úlohu aj ekonomické príčiny, kedy bohatšie Chorvátsko a Slovinsko prestali podporovat' chudobnejšie regióny. 
Tie sa samozrejme nechceli vzdat' finančných zdrojov a tak vypukli nepokoje (Rajec, 2011). V posledných rokoch, ako o závažnom konflikte v Európe, môžeme hovorit' o vojne na Donbase. Vojna na Ukrajine si podl'a odhadov vyžiadala už viac ako 10000 obetí.

Ďalšou významnou príčinou chudoby v Európe je nezamestnanost'. S tou sa stretávame hlavne v krajinách na Balkáne a v Pobaltí. Nezamestnanost' taktiež v posledných rokoch ovplyvnila aj hospodárska kríza. V Grécku sa napr. stretávame až s 26,3 \% podielom nezamestnanosti. Podl'a štatistík Eurostatu však môžeme hovorit' v posledných rokoch o značnom poklese v rámci všetkých štátoch Európy (www.ec.europa.eu, 2017). V porovnaní s vlaňajším januárom nezamestnanost' v regiónoch Európy klesla, a to o 0,8 percentuálneho bodu. Vysoká nezamestnanost' ale zostáva medzi mladými do 25 rokov. V EÚ predstavovala 17,7 \%, v eurozóne bola bez práce pätina mladých (www.finweb.hnonline.sk).

Medzi osobné príčiny chudoby $\mathrm{v}$ Európe môžeme zaradit' drogovú závislost', nízke sebavedomie alebo neracionálne plánovanie osobného finančného stavu a následná strata zamestnania či bývania. Tieto faktory zobrazujú chudobu z vel'mi subjektívneho hl'adiska a zväčša nemôžeme povedat', čo danú osobu viedlo $\mathrm{k}$ tomu, aby sa z nej stal chudobný jedinec. Je dôležité zdôraznit, že takéto osoby často krát zažívajú sociálne vylúčenie a je pre ne samotné vel'mi náročne dostat' sa z chudoby. So skupinou l'udí, ktorí sa takto stali chudobní zväčša súvisí aj sociálny jav bezdomovectva. Podl'a štatistík Eurostatu najviac osôb ktoré sú ohrozené bezdomovectvom žije v krajinách ako je Grécko, Írsko, Taliansko či Portugalsko kvôli už spomínanej kríze.

Medzi demografické pričiny patrí najmä vel'kost' rodiny. Všeobecne platí, že čím je väčšia rodina, tým väčšie je riziko chudoby. Ďalšou demografickou príčinou chudoby v Európe je pohlavie. Ženy sú všeobecne vystavené vyššiemu riziku chudoby ako muži. Taktiež je menej pravdepodobné že budú lepšie platené ako muži (www.poverty.org.uk, 2017).

Za jednu z hlavných príčin chudoby v Európe sa pokladá aj príslušnost’ $k$ etnickej menšine obyvatel'stva. Mareš (1999) uvádza, že škála životných stratégií príslušníkov etnických skupín je vel'mi vel'ká a siaha od aktivít v čiernej ekonomike až po plné spol'ahnutie sa na sociálny štát. Avšak pri spol'ahnutí sa na sociálny štát sa čast' príslušníkov etnickej minority mení na jeho závislých klientoch. V Nemecku napríklad sú najväčšie etnické minority tvorené Turkami, následne migrantmi z Balkánu a Pol'ska. V strednej Európe sa stretávame s vel'kým zastúpením rómskej menšiny. Pre rómsku chudobu je charakteristický jej vzt’ah k sociálnemu vylúčeniu. Aj ked’ sú slovenskí Rómovia etnicky rozmanití, ostatné obyvatel'stvo ich vníma ako homogénnu skupinu, od ktorej sa odlišuje. Pre vzt’ahy Rómov a majoritnej populácie je charakteristický vysoký stupeň vzájomnej sociálnej dištancie a nedostatok vzájomnej dôvery. 


\section{Záver}

Priestorová identifikácia jednotlivých aspektov chudoby má vo svete mnoho úskalí. Teritoriálne vymedzit' chudobu je z mnohých hl'adísk náročné. Podla toho, ako definujeme chudobu, aký koncept si zvolíme a aké indikátory budú predmetom sledovania, bude vyzerat' aj priestorové rozloženie chudoby.

Analýzou vybraných indikátorov chudoby je zrejmé, že najvyššia miera chudoby je v Afrike, Latinskej Amerike a Ázii. V Afrike je to hlavne čast' južne od Sahary, v Ázii je to Južná Ázia a v Amerike Stredná Amerika.

Indikátory, ktoré poskytuje Svetová banka a zároveň sa nimi dá získat' prehl'ad o chudobe vo svete, sú: hrubý priemerný príjem na osobu, nezamestnanost', gramotnost' populácie, hrubá miera úmrtnosti, odhadovaná dížka života pri narodení a iné.

Hrubý priemerný príjem na osobu je spomedzi regiónov sveta najnižší v Afrike, pričom vel'ká čast' štátov nedosahuje ani hodnotu 9000 \$. Niektoré krajiny sa k tejto hranici ani neblížia napr. v Stredoafrickej republike predstavoval tento indikátor len 620 \$ a v Libérii 720 \$. Pri analýze nezamestnanosti vieme identifikovat' dva regióny v Afrike, ktoré sú najviac postihnuté - ide hlavne o oblasti južnej a severozápadnej Afriky kde miera nezamestnanosti sa pohybuje okolo 20\% (Svazijsko, JAR, Líbya, Sudán). Gramotnost' populácie vykazuje najnižšie hodnoty v subsaharskej Afrike v štátoch Niger (19,1 \%), Čad (40 \%) a Sudán. Z Latinskej Ameriky je na tom najhoršie Guatemala (21 \%). Najmenší podiel gramotnosti v Ázii má Afganistan (38,2 \%). Najvyššie hodnoty hrubej miery úmrtnosti majú štáty v Afrike (Čad 14,06\%o, Stredoafrická republika s mierou $14,53 \%$, Somálsko $12,04 \%$ ). Odhadovaná dĺžka života pri narodení je najnižšia v afrických štátoch centrálnej Afriky (Kamerun 55 rokov), v štátoch juhovýchodného pobrežia (Mozambik 55 rokov) a taktiež na západe Afriky (Pobrežie Slonoviny 51 rokov).

\section{Literatúra}

AFRICA AND THE WORLD. 2017. The Worst leaders (Dictators) inf Africa Today. [online]. 2017. [cit. 2017-03-18]. Dostupné na internete: <http://www.africaw.com/the-worst-leaders-dictators-in-africatoday>.

ALCOCK, P. 1997. Understanding Poverty. Londýn: Macmillan Press LTD, 1997. 283 p. ISBN 0-333-69279-9.

AUSTRALIAN COUNCIL OF SOCIAL SERVICE. 2017. Child poverty on the rise: 730,000 children in poverty. [online]. 2017. [cit. 2017-04-03]. Dostupné na internete: <http://www.acoss.org.au/media_release/child-poverty-on-therise-730000-children-in-poverty/>.

BENCA, J. 2012. Tropické choroby. [online]. 2012. [cit. 2017-04-18]. Dostupné na 
internete: <http://ncpvat.cvtisr.sk/buxus/docs//Veda_v_CENTRE/_VvC-2012/vv c_201209_benca.pdf>.

BOLEČEKOVÁ, M. 2013. Chudoba a nástroje boja proti chudobe. In Rozvojové vzdelávanie: Témy a metódy. Bratislava : Nadácia Pontis, 2013. ISBN 978-80968229-9-7. s. 23-39.

CENTRUM PRE HOSPODÁRSKY ROZVOJ. 2013. Podoby chudoby na Slovensku. [online]. 2013. [cit. 2017-04-15]. Dostupné na internete: <http://www.cphr.sk/undp2000sl_06_cast3.pdf >.

CNN. 2013. Mexico Drug War Fast Facts. [online]. 2013. [cit. 2017-03-18]. Dostupné na internete: <http://edition.cnn.com/2013/09/02/world/ americas/mexico-drug-war-fast-facts/index.html $>$.

COLLIER, P. 2009. Miliarda nejchudších: Proč se některým zemím nedaři a co s tím?. Praha: Vyšehrad, 2009. 224 s. ISBN 978-80-7429010-7.

COUDOUEL, A. - HENTSCHEL, J. S. - WODON, Q. T. 2002. Poverty measurement and analysis. In A Sourcebook for poverty reduction strategies. Washington: World Bank, 2002. ISBN 0-8213-4978-3. s. 29-69.

EASTERLY, W. - LEVINE, R. 2017. Africa's growth tragedy: Policies and Ethnic Divisions. In The Quarterly Journal of Economics. vol 112, no. 4, pp. 12031250.

EUROSTAT. 2017. Štatistika migrácie a migrujúceho obyvatel'stva. [online]. 2017. [cit. 2017-04-19]. Dostupné na internete: <http://ec.europa.eu/ eurostat/statisticsexplained/index.php/Migration_and_migrant_population_stati stics/sk\#Po.C4.8Det_migrantov>.

FALŤAN, L. - PAŠIAK, J. 2004. Regionálny rozvoj Slovenska východiská a súčasný stav: Bratislava: Sociologický ústav Slovenskej akadémie vied, 2004. 88 s. ISBN 80-85544-35-0.

GORDON, D. 2017. Indicators of Poverty \& Hunger. [online] 2005. [cit. 2017-0130] Dostupné na internete: <http://www.un.org/esa/socdev/unyin/documents/ ydiDavidGordon_poverty.pdf >.

GREGORY, D. et al. 2011. The Dictionary of Human Geography. New Jersey: John Wiley \& Sons, 2011. 1072 p. ISBN 978-1-4051-3287-9.

HAUGHTON, J. - KHANDKER, S. R. 2009. Handbook on Poverty and Inequality. Washington: The World Bank, 2009. 442 p. ISBN 978-0821376133.

HOSPODÁRSKE NOVINY. 2017. Miera nezamestnanosti v EÚ klesla na dlhoročné minimum. [online]. 2017. [cit. 2017-04-10]. Dostupné na internete: $<$ http://finweb.hnonline.sk/ekonomika/920046-miera-nezamestnanosti-v-euklesla-na-dlhorocne-minimum>.

HÜBELOVÁ, D. 2010. Specifika demografického vývoje České republiky. In Sborník př́spěvků z mezinárodni vědecké konference Region v rozvoji společnosti 2010.

LANDES, D. S. 2004. Bohatství a bída národů. Praha: Jiří Buchal BB/art, 2004. 632 s. ISBN 80-7341-291-8. 
MAREŠ, P. 1999. Sociologie nerovnosti a chudoby. Praha: Sociologické nakladatelství, 1999, $248 \mathrm{~s}$. ISBN 80-85850-61-3.

MEASURES OF MATERIAL DEPRIVATION IN OECD COUNTRIES. 2017. [online]. 2017. [cit. 2017-04-18]. Dostupné na internete: <http://www.oecd.org/social/ soc/37223552.pdf

MICHÁLEK, A. 2000. Chudoba, jej koncepty a geografické dimenzie. In Geografický časopis. ISSN 0016-7192, 2000, roč. 52, č. 3, s. 231-242.

MICHÁLEK, A. 2004. Nepeňažné miery chudoby. In Otázky merania chudoby, Bratislava 2004, s. 65-72. ISBN 80-89149-02-2

MICHÁLEK, A. 2007. Regionálne mzdové nerovnosti na Slovensku. In Geografický časopis. Bratislava : Geografický ústav SAV, 2007, 59, 2. ISBN 1335-1257. s. 181- 1257.

MYDLOVÁ, A. - TOLMÁČI, L. 2013. Hlad vo svete a jeho príčiny. In Geographia Cassoviensis. ISSN 2454-0005, 2013, roč. 7, s. 100-110.

PEARCE, D. 1978. The feminization of poverty: Women, work, and welfare. In Urban and Social Change Review. ISSN 0042-0832, 1978, vol. 11, no. 1, pp. 28-36.

POVERTY IN FOCUS. 2006. [online]. 2006. [cit. 2017-01-30]. Dostupné na internete: 〈http://www.ipc-undp.org/pub/IPCPovertyInFocus9.pdf>.

RAJEC, F. 2011. Cesta t’ažko skúšanou krajinou. Bratislava: Fero Rajec, 2011. 198 s. ISBN 978-80-96-9848-5-7.

ROZVOJOVKA. 2016. Chudoba. [online]. 2016. [cit. 2016-12-01]. Dostupné na internete: <http://www.rozvojovka.cz/globalni-problemy/chudoba>.

RURAL POVERTY PORTAL. 2017. Region \& country. [online]. 2017. [cit. 201704-03]. Dostupné na internete: <http://www.ruralpovertyportal.org/region/ home/tags/oceania>.

SUMITOMO CORPORATION. 2017. The Contributions of San Cristobal Mine. [online]. 2017. [cit. 2017-03-18]. Dostupné na internete: <http://www. sumitomocorp.co.jp/english/business/article/id=232>.

SYRIAN OBSERVATORY FOR HUMAN RIGHTS. 2017. Local News. [online]. 2017. [cit. 2017-04-01]. Dostupné na internete: <http://www.syriahr.com/en/? cat $=46>$.

THE POVERTY SITE. 2017. Poverty and Inequality in the European Union. [online]. 2017. [cit. 2017-04-10]. Dostupné na internete: <http://www. poverty.org.uk/summary/eapn.shtml>.

THE WORLD BANK. 2016. Poverty: Overview. [online]. 2016. [cit. 2016-1201]. Dostupné na internete: <http://www.worldbank.org/en/topic/poverty/ overview>.

THE WORLD BANK. 2017. Adult literacy rate. [online]. 2017. [cit. 2017-03-17]. Dostupné na internete: <http://data.worldbank.org/indicator/SE.ADT.LITR. ZS>.

THOUGHTCO. 2017. Latin American Dictators. [online]. 2017. [cit. 2017-03-18]. 
Dostupné na internete: <https://www.thoughtco.com/latin-american-dictators2136482>.

UNITED NATIONS DEVELOPMENT PROGRAMME. 2017. [online]. 2017. [cit. 2017-03-18]. Dostupné na internete: 〈www.ipc-undp.org, 2017>.

VIRTUALLY. 2017. Statistická chudoba aneb Kdo je dnes doopravdy chudý? [online]. 2017. [cit. 2017-03-29]. Dostupné na internete: <http://virtually.cz/ archiv.php?art=17286>.

\section{MAJOR PROBLEM IN THE WORLD - POVERTY}

\section{Summary}

Spatial identification of individual aspects of poverty has many pitfalls in the world. Territorial specification is difficult in many ways. Spatial distribution of poverty depends on the definition of poverty, as well as on selected methods and indicators.

The analysis shows that the highest poverty rate is in Africa, Latin America and Asia. Applied indicators to analyze the poverty in the world are gross average earnings per person, unemployment rate, literacy of the population, gross mortality rate and estimated life expectancy at birth. The indicators are provided by World Bank.

Gross average earnings per person reached the lowest level in Africa. A large number of countries do not reach even $\$ 9000$. Some countries are not even close to this value, e.g. Central African Republic reached only \$ 620 and Liberia reached $\$ 720$. The most affected regions by unemployment are South Africa and Northwest Africa where unemployment level reached 20\% (Swaziland, RSA, Libya and Sudan). The lowest level of literacy was reached countries Niger (19.1\%), Chad (40\%), Sudan in Sub-Saharan Africa, Guatemala (21\%) in Latin America and Afghanistan (38,2\%) in Asia.

The highest level of gross mortality rate was recorded in Africa (Chad $14.6 \%$, Central African Republic - 14.53\%, Somalia - 12.04\%). The lowest values for estimated life expectancy at birth are captured in the African states of Central Africa (Cameroon 55 years), southeast coast (Mozambique 55 years) and west of Africa (Côte d'Ivoire 51 years).

\section{RNDr. PaedDr. Ján Veselovský, PhD.}

\section{Bc. Martin Peihoffner}

Katedra geografie a regionálneho rozvoja FPV UKF v Nitre

Trieda A. Hlinku 1, 94974 Nitra

E-mail: jveselovsky@ukf.sk, martin.peihoffner@student.ukf.sk 